九州大学学術情報リポジトリ

Kyushu University Institutional Repository

\title{
Experimental Comparison of Smoke Opacity and Particulate Matter Emissions with the Use of Emulsion Fuel
}

\section{Dhani Avianto Sugeng}

Advanced Vehicle System (AVS), Malaysia-Japan International Institute of Technology, Universiti Teknologi Malaysia

Wira Jazair Yahya

Advanced Vehicle System (AVS), Malaysia-Japan International Institute of Technology, Universiti Teknologi Malaysia

\section{Ahmad Muhsin Ithnin}

Advanced Vehicle System (AVS), Malaysia-Japan International Institute of Technology, Universiti Teknologi Malaysia

Badrul Hikmah Kusdi

Advanced Vehicle System (AVS), Malaysia-Japan International Institute of Technology, Universiti Teknologi Malaysia

他

https://doi.org/10.5109/4068626

出版情報：Evergreen. 7 (3)，pp.452-457，2020-09. 九州大学グリーンテクノロジー研究教育センター バージョン：

権利関係 : 


\title{
Experimental Comparison of Smoke Opacity and Particulate Matter Emissions with the Use of Emulsion Fuel
}

\author{
Dhani Avianto Sugeng ${ }^{1,2}$, Wira Jazair Yahya ${ }^{1, *}$, \\ Ahmad Muhsin Ithnin ${ }^{1}$, Badrul Hikmah Kusdi ${ }^{1}$, \\ Muhammad Adib Abdul Rashid ${ }^{1}$, Irfan Bahiuddin ${ }^{1,3}$, \\ Nurul Aiyshah Mazlan ${ }^{1}$, Hasannuddin Abd Kadir ${ }^{4}$ \\ ${ }^{1}$ Advanced Vehicle System (AVS), Malaysia-Japan International Institute of Technology, \\ Universiti Teknologi Malaysia, Kuala Lumpur, Malaysia \\ ${ }^{2}$ Center of Technology for Energy Resources and Chemical Industry (PTSEIK), \\ Badan Pengkajian dan Penerapan Teknologi, Jakarta, Indonesia \\ ${ }^{3}$ Department of Mechanical Engineering, Vocational College, \\ Universitas Gadjah Mada, Yogyakarta, Indonesia \\ ${ }^{4}$ Faculty of Mechanical Engineering, Universiti Teknologi MARA (UiTM) Johor, \\ Campus Pasir Gudang, Masai Johor, Malaysia
}

*Author to whom correspondence should be addressed:

E-mail: wira@utm.my

(Received January 21, 2020; Revised April 3, 2020; accepted September 3, 2020).

\begin{abstract}
Most studies reported that smoke opacity and particulate matter (PM) are substantially reduced when using emulsion fuel. The goal of this work was to predict the PM reduction of diesel emulsion fuel by measuring the smoke opacity, which is known to be proportional with PM. The smoke/PM measurements were mostly of the particulate trap type, which is lengthy, arduous and only offers cumulative results. In this study, the smoke opacity was measured in real-time by using a smoke opacimeter to obtain faster, simpler and continuous results. The results were compared to the results of Legal Particulate Sampling (LPS). The types of fuel used in this study were an emulsion fuel denoted as E10 and Malaysian EURO2 diesel (D2M). Even though the PM emission of E10 was $20 \%$ lower than D2M, the smoke opacity of E10 was $200 \%$ higher. It was concluded that the opacimeter could not be used to predict the PM reduction in emulsified D2M.
\end{abstract}

Keywords: particulate matter, smoke, water in diesel emulsion fuel, opacity, opacimeter.

\section{Introduction}

Industrial development has side implications which pollute the environment. Many developing cities are suffering from health problems and reduced visibility caused by smog and smoke/particulate matter (PM) emission. Diesel engines, the preferred engine for heavy and industrial applications, contribute to this environmental degradation by emitting large amounts of NOx, smoke and PM. Ecologically- aware cities have issued policies to reduce or outright ban the application of diesel engines ${ }^{1)}$.

Combustion in a diesel engine occurs under extremely diverse conditions with the continuously changing concentrations of gases, liquids, and solids. The chemical reactions of diesel combustion are incomplete, and PM exits from the exhaust, forming smoke. Generally, there are three kinds of smoke which form in a diesel engine: white, blue, and black smoke ${ }^{2}$. White smoke, which is observed at low loads or when it is cold-started, contains condensed water vapour and unburned fuel. It is triggered by local over-leanness or low combustion temperatures and usually disappears as the engine warms up ${ }^{2,3)}$.

Blue smoke is usually produced when the piston ring or valve guides are worn, causing the lubricant to enter the combustion chamber. On the other hand, black smoke is caused by unburned carbon particles (soot).

Soot, the main component of PM, is the solid microscopic carbon particles aerosolised in the exhaust gas. Soot is usually generated in a diesel engine at a temperature between 1000 and $2800 \mathrm{~K}$, at a pressure of $50-100 \mathrm{~atm}^{4}$. It is formed by thermal decomposition and dehydrogenation of the fuel in locally overrich regions of the combustion chamber ${ }^{2}$. When the particles are large 
enough, the aerosol is visible as smoke. A mixture of soot and droplets of liquid soluble fraction constitutes the PM, which is classified into PM10 and PM2.5. PM10 are generally $10 \mu \mathrm{m}$ and smaller, while PM2.5 are $2.5 \mu \mathrm{m}$ and smaller ${ }^{5}$. This size is considered an important factor in health aspects because they are lung carcinogen and the particles smaller than $10 \mu \mathrm{m}$ are more likely to enter deep into the respiratory system and bloodstream. Fine particles also create haze which reduces visibility ${ }^{6}$.

Table 1. Smoke and PM reductions by using $\mathrm{WD}^{\mathrm{a}}$

\begin{tabular}{|c|c|c|c|}
\hline 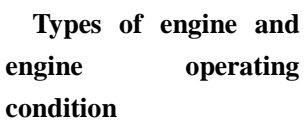 & $\begin{array}{l}\text { Water } \\
(\%)\end{array}$ & $\mathbf{P M}$ & $\begin{array}{r}\text { PM/Smoke } \\
\text { meas.method }\end{array}$ \\
\hline $\begin{array}{l}\text { 1-cylinder, light-duty, } \\
\text { direct-injection engine } \\
(\text { engine speed }=1250 \\
\text { rpm) }\end{array}$ & 40 & $\downarrow 2$ & $\begin{array}{l}\text { Smoke } \\
\text { Bosch }\end{array}$ \\
\hline $\begin{array}{l}\text { Bus, } 6 \text { cylinders, heavy } \\
\text { duty direct injection, } \\
\text { EURO } 2 \text { (MLTB cycle) }{ }^{8)}\end{array}$ & 10 & $\downarrow 2$ & $\begin{array}{l}\text { PM } \\
\text { LPS }\end{array}$ \\
\hline $\begin{array}{l}4 \text { cylinders, Displacement } \\
7118 \text { сc. The tests were }\end{array}$ & 10 & $\downarrow 1$ & $\begin{array}{l}\text { Smoke } \\
\text { Bosch }\end{array}$ \\
\hline $\begin{array}{l}\text { performed at } \mathrm{p}=5 \mathrm{bar} ; \mathrm{n} \\
=1700 \mathrm{rpm}^{9)}\end{array}$ & 15 & $\downarrow 2$ & \\
\hline 1-cylinder, Displacement & 5 & $\downarrow 1$ & $\mathrm{PM}$ \\
\hline $\begin{array}{l}406 \text { cc, } 5 \mathrm{~kW} .2 \% \text { SPAN80 } \\
\text { with an HLB } 4.3 \text { used as } \\
\text { the surfactant. Performed } \\
\text { at different loads }{ }^{10)}\end{array}$ & 10 & $\downarrow 2$ & LPS \\
\hline $\begin{array}{l}\text { 1-cylinder, } 5 \mathrm{~kW} \text {, } \\
\text { Displacement } 406 \text { cc. } \\
\text { Non-surfactant steam- } \\
\text { generated water-in-diesel } \\
\text { emulsion. Performed at } \\
\text { different loads }{ }^{11)}\end{array}$ & 6 & $\downarrow 3$ & $\begin{array}{l}\mathrm{PM} \\
\text { LPS }\end{array}$ \\
\hline $\begin{array}{l}\text { 1-cylinder, } 5 \mathrm{~kW} \text {, } \\
\text { Displacement } 406 \text { cc. } 1 \% \\
\text { SPAN80 with an HLB } 4.3 \\
\text { used as the surfactant. } \\
\text { Performed at different } \\
\text { loads }^{11}\end{array}$ & 10 & $\downarrow 2$ & $\begin{array}{l}\mathrm{PM} \\
\text { LPS }\end{array}$ \\
\hline
\end{tabular}

a=The symbols $\uparrow / \downarrow$ and 1,2,3,4 represent the trend and intensity of variations in each study, and cannot be used to compare different studies

Most modern diesel engines are equipped with silverbased catalysts to neutralize the PM emission ${ }^{12)}$. Also, introducing water into the combustion system can reduce PM emissions. Dryer observed in 1977 that water introduction by using emulsion fuel was proven to reduce the emission of NOx and PM ${ }^{13}$. Emulsion fuel for diesel engines is created by mixing water with diesel (WD) in the presence of a surfactant. The WD-related microexplosion phenomena enhance the atomization of the fuel during the premixing. The better premixing is believed to reduce the PM emission ${ }^{14-19)}$. Moreover, water content boosts the concentration of $\mathrm{OH}$ radicals, which consumes soot precursors by oxidation ${ }^{13)}$.

Previous studies, listed in Table 1, unanimously concluded that the PM emission could be substantially reduced by using emulsion fuel. Mazlan et al. from the AVS laboratory used a non-surfactant WD system (NWD) on a lorry, and observed a notable reduction in the produced NOx and smoke ${ }^{20}$. Sugeng et al. also employed an alternative NWD and gained a reduction on the NOx and $\mathrm{PM}$ reduction ${ }^{11)}$.

There are two types of measurements which can be indicative for PM or smoke intensity. Firstly, a Bosch type smoke meter (Bosch) or the Legal Particulate Sampling (LPS) captures the PM by trapping the particulates on a filter. With Bosch, the radiant flux of light reflected off the stained filter is measured at a scale of 0 to 10 by a portable, battery-powered photoelectric device ${ }^{21}$. With LPS, the difference of the filter before and after the particulate capture is compared. The disadvantages of both Bosch and LPS are that they are lengthy and arduous, yet offer only cumulative results. Secondly, smoke opacity is measured using an opacimeter, which indicates the reduction of a beam of light when passed through a gaseous medium. This measurement provides results in a real-time, simpler and continuous manner.

LPS and opacimeter results do correlate proportionally, which means lower PM results in lower smoke opacity ${ }^{22-}$ 25). Kihara from Horiba, offered the Equation (1) to calculate smoke opacity $\left(\mathrm{k}^{-1} \mathrm{~m}^{-1}\right)$ from PM concentration $\left(\rho_{P M} \text { in } \mathrm{kg} / \mathrm{m}^{3}\right)^{26)}$. In Equation (1), $\dot{\mathrm{m}}$ is the collected PM mass over the sampling duration $(\mathrm{kg} / \mathrm{s})$, C the conversion coefficient (m), and $\phi_{e x}$ the flow rate of the exhaust gas $\left(\mathrm{m}^{3} / \mathrm{s}\right)$.

$$
\dot{m}=C \cdot \rho_{P M} \cdot k \cdot \phi_{e x}
$$

However, no study has been found that presents any experimental data to confirm the conversion method. Thus, it was the objective of this study to provide empirical data to see whether an opacimeter can be used for the purpose of predicting the PM reduction in an emulsion fuel.

\section{Methodology}

The smoke opacity and particulate matter (PM) were measured under various loading conditions. The tests were performed on a Yanmar stationary diesel engine with the specifications listed in Table 2.

Table 2. Diesel engines specifications

\begin{tabular}{lc}
\hline No. of cylinders & 1 \\
Brand & Yanmar \\
Cylinder broke x stroke, mm & $85 \times 87$ \\
Displacement, l & 0.493 \\
Cooling system & Radiator \\
Continuous rated output, $\mathrm{kW}$ & 6.3 \\
\hline
\end{tabular}




\begin{tabular}{lc}
\hline Rated engine speed, rpm & 2400 \\
Operating speed during tests & 2000 \\
Compression ratio & $1: 18$ \\
\hline
\end{tabular}

The engine was fuelled with two types of fuel: Malaysian EURO2 diesel (D2M) as a baseline, and E10: an emulsified D2M with 10 vol\% water and 3 vol\% sorbitan monooleate (SM) of Sigma-Aldrich (SPAN80) as a surfactant ${ }^{19,27,28)}$. The properties of D2M are listed in Table 3.

The loads were delivered by a $10 \mathrm{~kW}$ KLAM eddycurrent dynamometer. The KLAM delivered a braking torque $(\mathrm{T})$ to the engine shaft. When the dyno was set to a specific load, some slip was observed. The measurements were initiated when the drop in the torque grip had somewhat stabilised. The actual torque was averaged between the maximum and minimum values during each measurement. Before the measurement was repeated, the torque was readjusted. The procedure was repeated 4 times, and the loads were calculated with engine speed (n) of 2000 rpm with Equation (2):

$$
P=\frac{2 \pi n T}{60}
$$

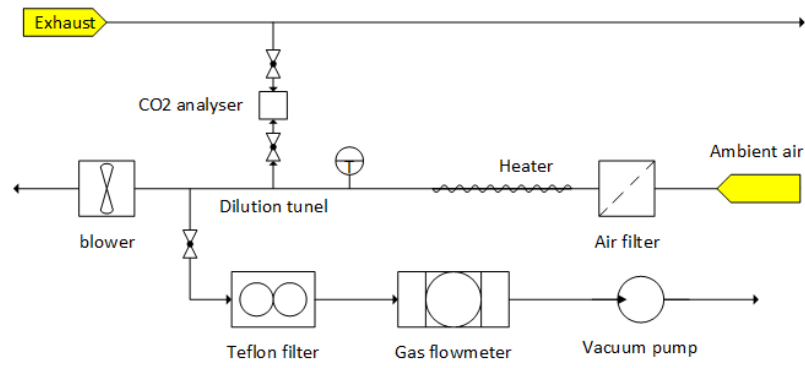

Fig. 1: Dilution tunnel schematics ${ }^{11)}$

The measurement of PM, schematised in Fig. 1, was performed by the Legal Particulate Sampling (LPS) using a custom-built dilution tunnel equipped with a Constant Volume Sampler (CVS). A desiccated MILLIPORE FHLP04700 Teflon filter (pore size $0.45 \mu \mathrm{m}$, diameter 47 $\mathrm{mm}$ ) trapped the PM. Loads were delivered incrementally from 1 to $5 \mathrm{~kW}$. The exhaust gas was diluted with ambient air. 200 litre of the diluted exhaust gas was led through the filter. The filter was desiccated again after the procedure. The difference between its weight before and after was assumed as PM.

The Horiba MEXA-600S is a light-transmitting type opacimeter that evaluates smoke concentration based on the intensity of the absorbed and scattered light when the light is aimed directly on the exhaust gas. The light transmission method has high sensitivity concerning blue and white smoke ${ }^{26)}$. The specifications of the MEXA600S are listed in Table 4.
Table 3. Malaysian EURO 2 Diesel (D2M) characteristics

\begin{tabular}{lcc}
\hline Properties & Unit & Value \\
\hline Calorific Value & $\mathrm{MJ} / \mathrm{kg}$ & 45.28 \\
Density @ $15^{\circ} \mathrm{C}$ & $\mathrm{kg} / \mathrm{L}$ & 0.8538 \\
Total Sulphur & mass \% & 0.28 \\
Maximum methyl-esther content & mass \% & 5 \\
Viscosity & $\mathrm{cSt}$ & $7.6 @ 20^{\circ} \mathrm{C}$ \\
& & $5.1 @ 40^{\circ} \mathrm{C}$ \\
& & $4.0 @ 60^{\circ} \mathrm{C}$ \\
Distillation Temperature, $90 \%$ recovery & ${ }^{\circ} \mathrm{C}$ & 367.9 \\
Flashpoint & ${ }^{\circ} \mathrm{C}$ & 93.0 \\
Pour Point & ${ }^{\circ} \mathrm{C}$ & 12 \\
Cetane Number & & 54.6 \\
Carbon & & 84.1 \\
Hydrogen & wt \% & 12.8 \\
Sulphur & wt \% & 0.2 \\
Nitrogen & wt \% & $<0.1$ \\
Oxygen & wt \% & 3.9 \\
\hline
\end{tabular}

Two types of tests were performed with the MEXA: rapid/free acceleration tests (FAT) and loaded steady-state $(\mathrm{LST})^{29)}$. Before the procedure were started, the engine was warmed up until $40^{\circ} \mathrm{C}$ to avoid unnecessary white smoke. Firstly, the FATs were performed under no-load condition by manually controlling the throttle handle. The engine was kept at idle speed of $600 \mathrm{rpm}$ for 5 seconds and then rapidly accelerated to the maximum speed of $2400 \mathrm{rpm}$. After 5 seconds at maximum speed, the throttle was released back to the original position. This cycle was repeated 10 times for each test, and the procedure was repeated 4 times. The values were then averaged as opacity $\mathrm{k}$ in $\mathrm{m}^{-1}$. Secondly, the LSTs were executed at a constant speed of $2000 \mathrm{rpm}$ at loads from 1 to $5 \mathrm{~kW}$. The opacity was then measured 4 times at each load.

Table 4. Horiba MEXA-600S opacimeter specifications

\begin{tabular}{ll}
\hline Measuring principle & $\begin{array}{l}\text { Opaque method } \\
\text { (partial flow sampling) }\end{array}$ \\
Light absorption coefficient (K) & $\begin{array}{l}0.000 \mathrm{~m}^{-1} \sim 9.999 \mathrm{~m}^{-1} \\
\text { Additional features }\end{array}$ \\
& $\begin{array}{l}\text { Oil temperature and engine speed } \\
\text { measurement }\end{array}$ \\
\hline
\end{tabular}

\section{Results and discussion}

The actual loads calculated with Equation (2) were recorded, and the results are tabulated in Table 5 . The torque was set to $23.84 \mathrm{Nm}$ to produce a power of $5 \mathrm{~kW}$ at $2000 \mathrm{rpm}$. Because of the magnitude, the current that runs through the stators became substantial and generated excessive heat, which the cooling fan could not compensate. The heat caused the dyno to trip and inoperable until it cooled down. Hence, the measurements 
were only performed up to $4 \mathrm{~kW}$.

Table 5. Set and actual torque/loads at $2000 \mathrm{rpm}$

\begin{tabular}{cccc}
\hline $\begin{array}{c}\text { Set } \\
\text { value } \\
(\mathrm{kW})\end{array}$ & $\begin{array}{c}\text { Torque } \\
(\text { set }) \\
(\mathrm{Nm})\end{array}$ & $\begin{array}{c}\text { Actual } \\
\text { torque } \\
(\mathrm{Nm})\end{array}$ & $\begin{array}{c}\text { Actual } \\
\text { load }(\mathrm{kW})\end{array}$ \\
\hline 1 & 4.7746 & 4.6403 & 0.9719 \\
2 & 9.5493 & 9.7165 & 2.0350 \\
3 & 14.3239 & 14.3223 & 2.9997 \\
4 & 19.0986 & 19.1633 & 4.0136 \\
5 & 23.8372 & - & - \\
\hline
\end{tabular}

The actual torques and loads were averaged, and the standard deviations were calculated. The results are depicted in Fig. 2. It can be observed that the error was minimal, indicating a reproducible load during all the 4 load tests.

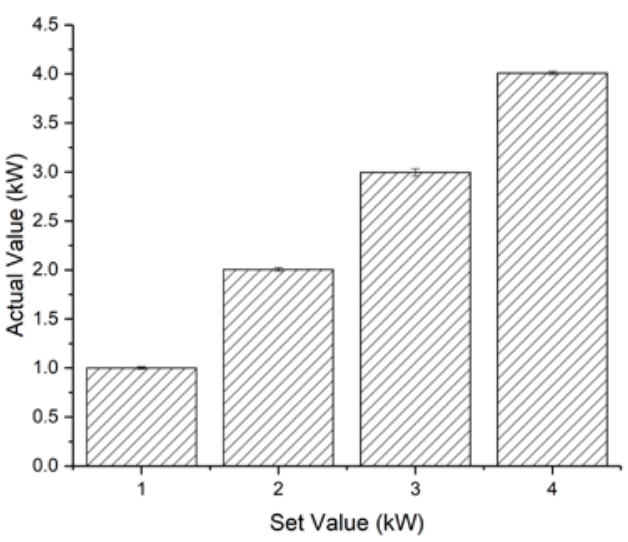

Fig. 2: Set and actual brake power at $2000 \mathrm{rpm}$

The results of LPS are represented in Fig. 3, where it can be observed for each fuel, that the PM concentrations decreased notably with increasing load. Compared to D2M, E10 showed a reduction between 13 to $20 \%$. According to Black et al. ${ }^{22)}$, we would expect the smoke opacity also to be reduced.

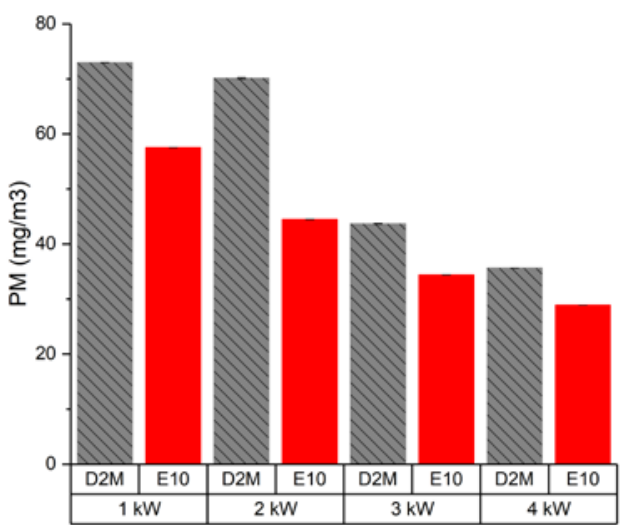

Fig. 3: PM measurements results
The results of the FAT with E10 and D2M are given in Fig. 4. The average D2M's opacity was somewhat lower than E10, which is contradicting the lower value of E10's PM. However, the standard deviation spread renders these results inconclusive. The spread might be caused by the inconsistencies during the FAT accelerating cycles. The MEXA manual suggested that the acceleration to the maximum engine speed is executed within 2 seconds. Still, since the operation was manually performed, the acceleration rise might also vary for each cycle. It should be noted that during the transient FAT runs with E10; the smoke was notably whitish.

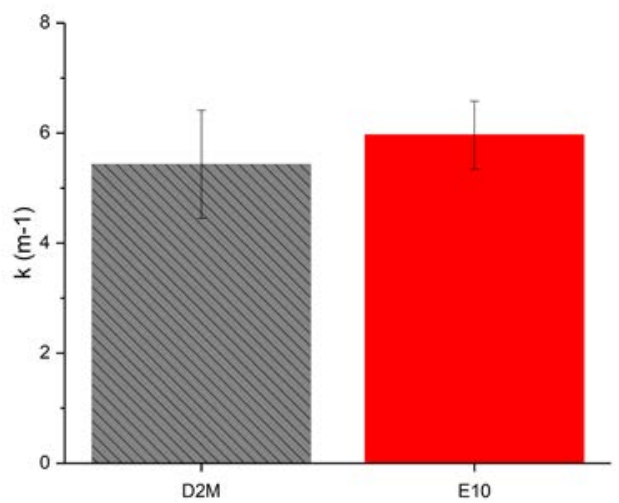

Fig. 4: Transient FAT results

LST tests yielded more resounding results in Fig. 5, with the overall higher smoke opacity of E10 compared to D2M. Again, these results contradicted the lower E10's LPS results. Each fuel showed increasing opacity values across the increasing loads. With the LST runs, the white smoke was not as apparent but could play some role in heightening the opacity of the smoke.

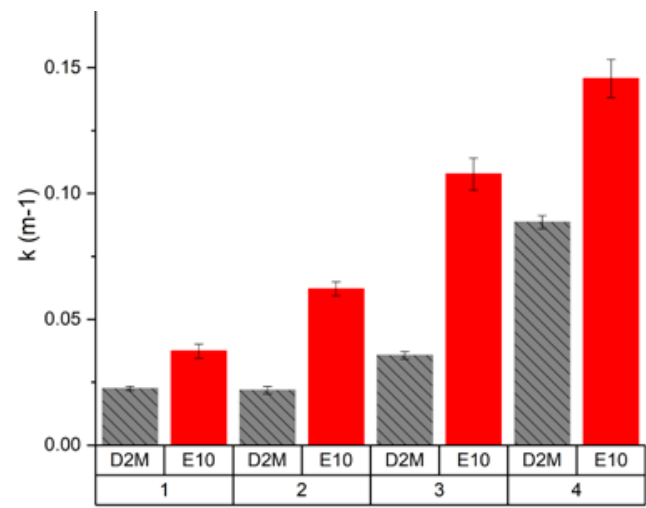

Fig. 5: Loaded steady-state (LST) smoke opacity 
When the PM measurements were processed with Equation (1), the opacity k could then be compared and displayed in Fig. 6. Firstly, the calculated opacity $\left(\mathrm{D}_{2} \mathrm{M}_{\mathrm{c}}\right)$ at lower loads up to $3 \mathrm{~kW}$ showed close approximations with the measured opacity of D2M (D2M $\left.\mathrm{M}_{\mathrm{m}}\right)$. However, at the higher load of $4 \mathrm{~kW}, \mathrm{D}_{2} \mathrm{M}_{\mathrm{m}}$ jumped and differed significantly than $\mathrm{D}_{2} \mathrm{M}_{\mathrm{c}}$. The jump was most probably caused by incomplete combustion of D2M at high loads.

Secondly, D2M $\mathrm{C}_{\mathrm{c}}$ shows overall higher values than

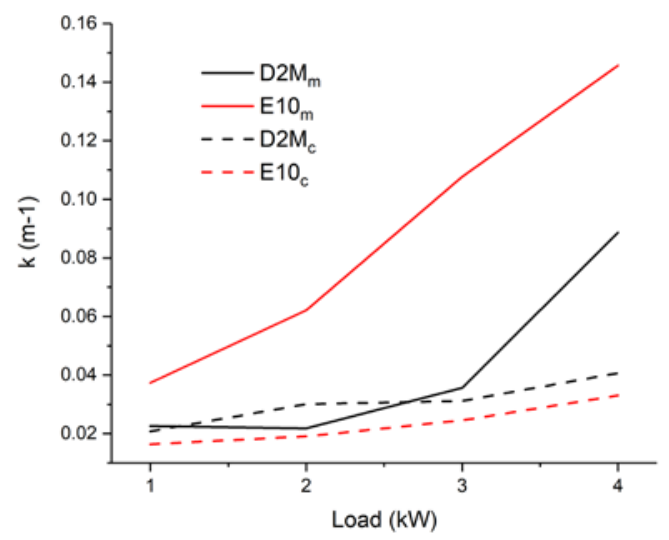

Fig. 6: Comparison of measured (m) and calculated (c) k

E10's calculated value $\left(\mathrm{E} 10_{\mathrm{c}}\right)$. E10 showed a wide gap between measured value $\left(\mathrm{E} 10_{\mathrm{m}}\right)$ and $\mathrm{E} 10_{\mathrm{c}}$. The big difference between $\mathrm{E} 10_{\mathrm{m}}$ and $\mathrm{E} 10_{\mathrm{c}}$ might be caused by the presence of opaque water vapour. Excessive white smoke emission was also a side product incomplete combustion due to the reduction of the E10's combustion temperatures. In LPS, the water mass was undetected because most of it was eliminated by desiccation.

In contrast with E10 and D2M, other studies on the emulsion of biodiesel, such as wood-pyrolysis oil ${ }^{30)}$, jatropha methyl esters ${ }^{30,31)}$, lemongrass oil ${ }^{32)}$ reported lower opacities of their smoke compared to their respective base fuel. These results could be attributed to the fact that the biofuels are oxygenated enough to compensate for the incomplete combustion observed in D2M.

\section{Conclusion}

This study collected and compared the results of Legal Particulate Sampling and an opacimeter. Overall, the opacimeter is more convenient to use than LPS. However, analysis of the results showed that the opacities of D2M and E10 did not correlate with PM. Although E10 generated lower PM than D2M, the smoke opacity of E10 are generally higher. The white smoke generated due to the water content in E10 contributed to the opacity of the exhaust gas, causing a large gap between the measured and calculated values.

\section{Acknowledgement}

Highest appreciation goes to the Ministry of Higher Education Malaysia and Universiti Teknologi Malaysia for their financial support through UTM Transdisciplinary Research Grant (Q.K130000.3543.05G48)

\section{References}

1) T. Sato, "How is a sustainable society established? a case study of cities in japan and germany,” Evergreen, 3 (2) 25-35 (2016). doi:10.5109/1800869.

2) C.O. Miller, "Diesel Smoke Suppression by Fuel Additive Treatment,” in: 1967. doi:10.4271/670093.

3) M.K. Yassine, M.K. Tagomori, N.A. Henein, and W. Bryzik, "White Smoke Emissions Under Cold Starting of Diesel Engines,” in: SAE Tech. Pap., SAE International, 1996. doi:10.4271/960249.

4) S. Mohankumar, and P. Senthilkumar, "Particulate matter formation and its control methodologies for diesel engine: a comprehensive review," Renew. Sustain. Energy Rev., 80 1227-1238 (2017). doi:10.1016/j.rser.2017.05.133.

5) O. US EPA, "Particulate matter (pm) basics,” (2018). https:/www.epa.gov/pm-pollution/particulatematter-pm-basics (accessed November 25, 2018).

6) O. Raaschou-Nielsen, R. Beelen, M. Wang, G. Hoek, Z.J.J. Andersen, B. Hoffmann, M. Stafoggia, P. Vineis, et al., "Particulate matter air pollution components and risk for lung cancer,” Environ. Int., 87 66-73 (2016). doi:10.1016/J.ENVINT.2015.11.007.

7) K.A. Subramanian, and A. Ramesh, "Experimental investigation on the use of water diesel emulsion with oxygen enriched air in a di diesel engine," SAE Pap., 2001-01-02 (724) (2001). doi:10.4271/2001-01-0205.

8) A. Barnes, D. Duncan, J. Marshall, A. Psaila, J. Chadderton, and A. Eastlake, "Evaluation of waterblend fuels in a city bus and an assessment of performance with emission control devices," Int. Spring Fuels Lubr. Meet. Expo., (724) (2000). doi:10.4271/2000-01-1915.

9) N. Samec, B. Kegl, and R.W. Dibble, "Numerical and experimental study of water/oil emulsified fuel combustion in a diesel engine,” Fuel, 81 (16) 2035 2044 (2002). doi:10.1016/S0016-2361(02)00135-7.

10) A.M. Ithnin, W.J. Yahya, M.A. Ahmad, N.A. Ramlan, H. Abdul Kadir, N.A.C. Sidik, T. Koga, H.A. Kadir, A. Ramlan, and W.J. Yahya, "Emulsifier-free waterin-diesel emulsion fuel: its stability behaviour, engine performance and exhaust emission," Fuel, 215 (November 2017) 454-462 (2018). doi:10.1016/J.FUEL.2017.11.061.

11) D.A. Sugeng, W.J. Yahya, A.M. Ithnin, M. Adib, A. Rashid, N. Salsabilla, M. Syahril, H.A. Kadir, M. Naim, and A. Halim, "Diesel engine emission analysis using fuel from diverse emulsification methods,” Environ. Sci. Pollut. Res., (2018). 
12) H. Ruan, M. Nishibori, T. Uchiyama, K. Kamitani, and K. Shimanoe, "Soot oxidation activity of ag/hzsm-5 (si/al=40) catalyst,” Evergreen, 4 (2/3) 711 (2017).

13) F.L. Dryer, "Water addition to practical combustion systems-concepts and applications," Symp. Combust., $16 \quad$ (1) 279-295 (1977). doi:10.1016/S0082-0784(77)80332-9.

14) A.M. Ithnin, H. Noge, H.A. Kadir, and W. Jazair, “An overview of utilizing water-in-diesel emulsion fuel in diesel engine and its potential research study," $J$. Energy Inst., $87 \quad$ (4) 273-288 (2014). doi:10.1016/j.joei.2014.04.002.

15) J.M. Ballester, N. Fueyo, and C. Dopazo, "Combustion characteristics of heavy oil-water emulsions,” Fuel, 75 (6) 695-705 (1996). doi:10.1016/0016-2361(95)00309-6.

16) W. Biao Fu, L. Yun Hou, L. Wang, F. Hua Ma, W.B. Fu, L.Y. Hou, L. Wang, and F.H. Ma, “A unified model for the micro-explosion of emulsified droplets of oil and water," Fuel Process. Technol., 79 (2) 107119 (2002). doi:10.1016/S0378-3820(02)00106-6.

17) M.A.A.A.A. Nazha, and R.J.J. Crookes, "Effect of water content on pollutant formation in a burning spray of water-in-diesel fuel emulsion,” Symp. Combust., $20 \quad$ (1) 2001-2010 (1985). doi:10.1016/S0082-0784(85)80700-1.

18) R. Ochoterena, A. Lif, M. Nydén, S. Andersson, and I. Denbratt, "Optical studies of spray development and combustion of water-in-diesel emulsion and microemulsion fuels,” Fuel, 89 (1) 122-132 (2010). doi:10.1016/j.fuel.2009.06.039.

19) A. Maiboom, and X. Tauzia, "NOx and pm emissions reduction on an automotive hsdi diesel engine with water-in-diesel emulsion and egr: an experimental study,” Fuel, 90 (11) 3179-3192 (2011). doi:10.1016/j.fuel.2011.06.014.

20) N.A. Mazlan, W.J. Yahya, A.M. Ithnin, A.K.K. Hasannuddin, N.A. Ramlan, D.A. Sugeng, A.R.R. Muhammad Adib, T. Koga, R. Mamat, and N. Azwadi, "Effects of different water percentages in nonsurfactant emulsion fuel on performance and exhaust emissions of a light-duty truck," J. Clean. Prod., (2018). doi:10.1016/j.jclepro.2018.01.143.

21) A.C. Alkidas, "Relationships Between Smoke Measurements and Particulate Measurements," in: SAE Tech. Pap., SAE International, 1984. doi:10.4271/840412.

22) J. Black, P.G. Eastwood, K. Tufail, T. Winstanley, Y. Hardalupas, and A.M.K.P. Taylor, "Inter-correlations between smoke opacity, Legal Particulate Sampling (LPS) and TEOM, during transient operation of a diesel engine,” in: SAE Tech. Pap., SAE International, 2007. doi:10.4271/2007-01-2060.

23) D.M. Roessler, and F.R. Faxvog, “Opacity of black smoke: calculated variation with particle size and refractive index,” Appl. Opt., 18 (9) 1399-1403
(1979). doi:10.1364/AO.18.001399.

24) D.M. Roessler, "Opacity and Photoacoustic Measurements of Diesel Particle Mass Emissions," in: SAE Tech. Pap., SAE International, 1982. doi:10.4271/820460.

25) A. Bertola, R. Schubiger, A. Kasper, U. Matter, A.M. Forss, M. Mohr, K. Boulouchos, and T. Lutz, "Characterization of Diesel Particulate Emissions in Heavy-Duty DI-Diesel Engines with Common Rail Fuel Injection Influence of Injection Parameters and Fuel Composition,” in: SAE Tech. Pap., SAE International, 2001. doi:10.4271/2001-01-3573.

26) N. Kihara, "Opacimeter mexa-130s," Horiba - Tec. Reports, 45-50 (2002).

27) M.E.A. Fahd, Y. Wenming, P.S. Lee, S.K. Chou, and C.R. Yap, "Experimental investigation of the performance and emission characteristics of direct injection diesel engine by water emulsion diesel under varying engine load condition,” Appl. Energy, 102 1042-1049

(2013) doi:10.1016/j.apenergy.2012.06.041.

28) M.Y.E. Selim, and M.T. Ghannam, "Combustion study of stabilized water-in-diesel fuel emulsion," Energy Sources, Part A Recover. Util. Environ. Eff., 32 (3) 256-274 (2009). doi:10.1080/15567030802467621.

29) DEFRA, "Appendix 2 review of test procedures contents,” (n.d.).

30) R. Prakash, R.K.K. Singh, and S. Murugan, "Experimental studies on combustion, performance and emission characteristics of diesel engine using different biodiesel bio oil emulsions,” J. Energy Inst., $88 \quad$ (1) $\quad 64-75 \quad$ (2015). doi:10.1016/J.JOEI.2014.04.005.

31) J. Sadhik Basha, and R.B. Anand, "Performance, emission and combustion characteristics of a diesel engine using carbon nanotubes blended jatropha methyl ester emulsions,” Alexandria Eng. J., 53 (2) 259-273 (2014). doi:10.1016/j.aej.2014.04.001.

32) M. Annamalai, B. Dhinesh, K. Nanthagopal, P. SivaramaKrishnan, J. Isaac JoshuaRamesh Lalvani, M. Parthasarathy, and K. Annamalai, “An assessment on performance, combustion and emission behavior of a diesel engine powered by ceria nanoparticle blended emulsified biofuel," Energy Convers. Manag., $123 \quad 372-380 \quad$ (2016). doi:10.1016/J.ENCONMAN.2016.06.062. 